\title{
Unravelling Vietnamese Students' Critical Thinking and Its Relationship with Argumentative Writing
}

\author{
Tuyen Son Nguyen ${ }^{1}$, Huan Buu Nguyen ${ }^{2, *}$ \\ ${ }^{1}$ Vinh Long Foreign Language Center, Vietnam \\ ${ }^{2}$ School of Foreign Languages, Can Tho University, Vietnam
}

Received August 25, 2020; Revised September 29, 2020; Accepted October 25, 2020

\section{Cite This Paper in the following Citation Styles}

(a): [1] Tuyen Son Nguyen, Huan Buu Nguyen, "Unravelling Vietnamese Students' Critical Thinking and Its Relationship with Argumentative Writing," Universal Journal of Educational Research, Vol. 8, No. 11B, pp. 5972 - 5985, 2020. DOI: 10.13189/ujer.2020.082233.

(b): Tuyen Son Nguyen1, Huan Buu Nguyen (2020). Unravelling Vietnamese Students' Critical Thinking and Its Relationship with Argumentative Writing. Universal Journal of Educational Research, 8(11B), 5972 - 5985. DOI: 10.13189/ujer.2020.082233.

Copyright $\subseteq 2020$ by authors, all rights reserved. Authors agree that this article remains permanently open access under the terms of the Creative Commons Attribution License 4.0 International License

\begin{abstract}
Critical thinking has been recognized as a key academic skill due to its role in the learning process, especially in higher education, and particularly in second and foreign language teaching and learning of writing. This thinking pattern is crucial in Vietnamese tertiary education since in the globalized world of information. There has been increased demand for students to gain greater depth of subject-specific knowledge and develop their ability to synthesize, process, and evaluate different sources of texts for the sake of meeting the needs of their own academia and future studies. However, it is quite a new concept in Vietnamese educational system and few studies have been conducted to examine critical thinking in relation to argumentative writing. This paper, henceforth, reports a descriptive study that investigates the critical thinking ability of Vietnamese EFL (English as a foreign language) university students and its relationship with their writing argumentative essays. Data collected in this study include a questionnaire and an essay writing test. Participants were 126 EFL students at three universities in the Mekong delta, Vietnam. The findings reveal that Vietnamese EFL university students' critical thinking is at high level while it was statistically insignificant that a relationship between their critical thinking and their argumentative writing existed. The obtained results indicate that instructional methods and activities employed by Vietnamese EFL teachers in universities of the Mekong region may well promote cognitive development of their students. It also suggests urgent actions from EFL teachers and stake-holders to seek for feasible solutions to foster
\end{abstract}

students' implementation of their cognitive skills into their writing and other language skills.

Keywords Critical Thinking, Argumentative Writing, EFL, Higher Education, English Majors

\section{Introduction}

Critical thinking has been acknowledged as a core academic skill because of its significance in the learning process [1, 2]. According to the six cognitive levels of Bloom's taxonomy, the last three highest forms of cognition, namely analyzing, evaluating, and creating, which are the basic of critical thinking, are the goal of educational objectives, especially in higher education [3]. Many countries around the world have implemented critical thinking into their teaching and learning practices. more and more schools in Asia such as Singapore, Malaysia, China [4], and Indonesia [5] shared a similar trend. Understanding the global tendency, Vietnam has recently introduced elements of higher order of thinking skills into the new general education program about to take effects in the academic years of 2020-2021 [6].

Critical thinking skills and language skills are reported to be closely related $[5,7,8]$. It can be reflected through productive skills such as writing, especially argumentative writing due to its requirements in analyzing situations, problem-solving, and clarifying opinions. However, 
writing is a complex and challenging task to both first language and second language writers [9]. One of the problems with students' writing is their lack of cohesion and coherence. That is to say, they struggle with developing their ideas in an organized and logical manner. Researchers have argued that the cause of this issue may not be students' lack of knowledge in the subject but their lack of critical thinking [7]. Should language teachers be well informed of the relationship between critical thinking and argumentative writing, it may entice them to search for appropriate teaching practices to promote students' critical thinking skills and their argumentative writing performance. It is especially useful in the Vietnamese teaching and learning context because critical thinking is still a new concept in Vietnamese education.

The focus of this research, therefore, is to unpack the critical thinking ability of Vietnamese university students and the relationship between critical thinking and their writing argumentative essays.

\section{Literature Review}

\subsection{Critical Thinking}

\section{A. Defining critical thinking}

Over time, an extensive literature has been done to define 'critical thinking'. Despite numerous attempts to provide apposite definitions, the term is still to be redefined as it is not easy to come to consensus.

Critical thinking can be traced back to as far as 2,500 years ago when the ancient Greek teacher, scholar, and philosopher Socrates revealed that provocative questioning could uncover one's rational self-consciousness [10]. Educator Dewey [11], however, is often cited as the first to coin the term 'reflective thinking' [12]. This term refers to the kind of thinking that comprises of 'turning a subject over in the mind' and considering it seriously and consecutively [2].

According to Bloom and his colleagues [13], critical thinking is generalized as 'intellectual abilities and skills' that individuals can apply appropriate knowledge and strategies from their previous experiences to new issues and circumstances [13]. This notion is agreed by Moon [3] as she associates critical thinking with "tools of manipulation of knowledge" (p.25). She points out that the process of critical thinking involves generating prior knowledge ("internal experience") and external material ("external experience”) while thinking critically about one's own actions or ideas before making a judgment.

A simple definition is defined by Professor Robert Ennis [14]. He believes that critical thinking is a hands-on practice. It is reflective and reasonable thinking activities that help individuals "decide what to believe or do" [14]. In other words, critical thinking, according to Ennis, focuses on reasonableness, reflection, and the process of decision-making [15].
In their extensive study, a panel of forty-six critical thinking experts (including Professor Ennis as mentioned previously) reaches a consensus that critical thinking is a form of "higher-order thinking" together with problem-solving, decision-making, creative thinking and the like [16]. Critical thinking, which is a 'purposeful' and 'pervasive' human phenomenon, is a crucial tool in the process of discovering facts about a subject [16]. Situations such as IT technicians programming a computer, lawyers defending their clients, or a man helping his friend fix his vehicle, are examples for critical thinking to be applied in individual lives [16].

Similarly, the American psychologist and professor Halpern, in her overview of working definitions of critical thinking, highlights that critical thinking is purposeful, reasoned, and goal directed [17]. It gives evidence and reasons to overcome individual biases.

Moreover, it is worth noting that critical thinking is different from "being critical” or "criticizing” which often carry negative connotations [3, 17]. Instead, critical thinking denotes "constructive reflections" of evaluating one's thought processes and their outcomes [17].

Despite the plethora of critical thinking's definitions, a general conception can be concluded about critical thinking. It can be understood as the ability to objectively make well-informed and rational judgments and decisions. This skill is crucial in education [1, 3], especially in language learning as it promotes effective communication [16].

\section{B. Core critical thinking skills}

In the scope of this study, core critical thinking skills are in accordance with The Delphi Report [16]. After a two-year study, a panel of forty-six critical thinking experts came to an agreement that critical thinking includes six core skills: analysis, evaluation, interpretation, inference, explanation, and self-regulation. Each core skills come with several sub-skills which are summarized in Table 1.

Table 1. Critical thinking and sub-skills (Facione,1990)

\begin{tabular}{|c|c|}
\hline Skills & Sub-skills \\
\hline \multirow{3}{*}{ 1. Analysis } & Examining ideas \\
\cline { 2 - 2 } & Identifying arguments \\
\cline { 2 - 2 } & Analyzing arguments \\
\hline \multirow{2}{*}{ 2. Evaluation } & Assessing claims \\
\cline { 2 - 2 } & Assessing arguments \\
\hline \multirow{2}{*}{ 3. Interpretation } & Categorization \\
\cline { 2 - 2 } & Decoding significance \\
\hline \multirow{3}{*}{ 4. Inference } & Clarifying meaning \\
\cline { 2 - 2 } & Querying evidence \\
\cline { 2 - 2 } & Conjecturing alternatives \\
\hline \multirow{3}{*}{ 5. Explanation } & Drawing conclusions \\
\cline { 2 - 2 } & Stating results \\
\cline { 2 - 2 } & Justifying procedures \\
\hline \multirow{2}{*}{ 6. Self-Regulation } & Presenting arguments \\
\cline { 2 - 2 } & Self-examination \\
\cline { 2 - 2 } & Self-correction \\
\hline
\end{tabular}




\section{Critical thinking skills in Asia}

Few empirical studies have been published on the critical thinking levels of Asian students, including Vietnamese. For instance, to explore the effects of questions on high school students' critical thinking ability in learning Literature, Lam [18] studied 32 grade-11 learners at a high school in a rural area of the Mekong delta. In order to measure the critical thinking levels of the participants prior to the experimental study, the students were asked to write down their opinion about a well-known Vietnamese legend named "My Chau - Trong Thuy". Based on the way they responded to the questions (e.g., accurately aimed at the target questions, applied knowledge and evidence appropriately to debate), their critical thinking levels would be ranked in accordance with the marking rubric. The outcomes of her study suggest that Vietnamese high school students were mostly weak and average at critical thinking.

A similar conclusion was found in a doctoral thesis [19]. Nguyen explores critical thinking practices in a Vietnamese EFL context at a tertiary level. The qualitative study included twenty observations of two class types: 14 skills-based and 6 content-based classes. Semi-interviews on 8 teachers and 22 students were also carried out. One of her findings is that Vietnamese EFL university students were believed to be weak at thinking critically as perceived by their teachers. This finding is limited to personal perceptions rather than a verifiable measurement.

On the other hand, D.T.K. Nguyen [20] adapts a verified instrument to measure the participants' critical thinking in her master thesis. In order to investigate the impacts of problem-based learning on the development of students' critical thinking, she conducted an experimental study on 80 non-English major seniors at a college in a province of the Mekong delta. The instrument used to estimate students' critical thinking is the California critical thinking disposition inventory questionnaire. Although Nguyen did not specify the critical thinking level of the students, it can be inferred from the data outcomes that Vietnamese non-English majored students were at average level (mean=3.07, SD=.58) (p.30). The instrument of her study, however, is not intended to measure critical thinking skills or ability as admitted by the author herself. Instead, it is designed for the purpose of evaluating the disposition dimension or the internal motivation to use critical thinking skills.

In other Asian context such as China, Pei and his associates reveals that Chinese EFL students are not strong at critical thinking skills [4]. They lack demonstrations of these skills such as direct questioning or debating ideas in class. Similarly, Okada surveyed 1,481 Japanese high school students and 277 Japanese freshmen and sophomores who studied information and telecommunications engineering in a private university in Japan [21]. Results from the survey show that Japanese students have difficulty in presenting their verbal opinions and ideas. According to Okada, traditional Japanese cultures and values of harmony prevents learners from raising questions and expressing their thoughts which are manifestations of critical thinkers. Vietnam, as a Confucian-influenced country like Japan and China [22], shares similar cultural values. Hence, it can be assumed that students of Vietnamese cultures may display corresponding characteristics in terms of critical thinking. Nonetheless, as noted, despites the literature about issues regarding teaching and learning critical thinking in Vietnamese education, evidence of students' current critical thinking skills remains to be addressed. For these reasons, the purpose of this present study is reinforced.

\subsection{Argumentative Writing}

\section{A. Defining argumentative writing}

Writing is a language skill in which writers transfer their thoughts and ideas into comprehensibly written forms to communicate with readers. Different communicative purposes require different genres of writing such as academic writing (lab reports, theses, dissertations), job-related writing (business emails, announcements, schedules), or personal writing (diaries, invitations, greeting cards) [23]. Targeted readers also determine the writing style: informal among peers, and formal in professional or academic contexts.

Argumentative writing is an important genre of writing [24]. It can be defined by its purpose to convince readers about the correctness of a central statement. In order to persuade the readers, an argumentative writing must present relevant points with supporting evidence [25]. An example for this genre is an essay to argue about the urge to make higher education free for everybody. With the aim of getting readers on the writer's side, he or she must demonstrate the benefits and necessity of free tertiary-level education, and the like.

\section{B. Elements of argumentative writing}

According to the British linguist and professor Ken Hyland, argumentative essay writing involves a three-stage structure that represents the organization of this genre [24]. They are thesis, argument, and conclusion. First, the thesis plays an introductory role. It identifies the proposition or the topic to be argued. That includes background for contextualizing, and a statement of the writer's viewpoints. Second, argument is presented in the essay's body. Reasons for the thesis statement are discussed in this part. Besides examples, explanations, evidence to support the writer's position, a refutation or counter argumentation of the other perspectives can be considered to strengthen the author's point of view. Finally, a conclusion is drawn to synthesize the discussion and affirms the thesis' validity. An effective conclusion may extend the context to wider circumstances. 


\subsection{Related Studies}

Although plethoras of studies have shown that critical thinking and writing have a positive correlation, few studies indicate the opposite.

Positive correlation between critical thinking and writing. Many empirical studies have supported the positive correlation between critical thinking and writing [e.g., 5, 7, 26, 27-30]. For instance, in 2014, in order to examine the correlation between Iranian EFL learners' critical thinking and their argumentative writing achievement. Hashemi and his associates studied 178 EFL learners from three universities in Iran. After employing the Watson-Glaser Critical Thinking Appraisal and an argumentative writing assignment, they found a significant relationship between the two variables. Likewise, evidence from study on first-year Chilean EFL students reveal a positive correlation between critical thinking and argumentative writing [27].

This relationship is further reflected in other studies such as that by Nejmaoui's [28]. Aiming to explore the effect of integrating critical thinking skills in argumentative writing, 36 Moroccan EFL university students were divided into an experimental group and a control group. The first one was taught writing together with critical thinking skills while the other received only writing instructions with no reference of critical thinking skills. After one semester, results from the pre-test and post-test indicate a development in learners' use of critical thinking skills in writing argumentative essays. For example, students can use evidence to support their arguments in a clearer and more credible fashion. They can also consider alternative positions as well as maintain a logical organization of ideas in their essays. Although their improvements did not reach a mastery level, it was an encouraging outcome considering the short period of treatment time. In other words, integrating critical thinking skills into writing instructions bring positive effects on learners' writing argumentative essays.

In a similar manner, Fahim and Mirzaii [30] claim that combining dialogic critical thinking into writing instruction can enhance the quality of students' argumentative writing. Furthermore, Widyastuti's [29] study on students of an English literature program in Indonesia suggests that integrating critical thinking aspects into argumentative writing could improve learners' English language competence in addition to critical thinking skills.

No or negative correlation between critical thinking and writing. Despite the long-held belief that writing and thinking are inevitably linked, few studies such as those of Condon and Kelly-Riley [31], or Pei and his colleagues [4] disprove such assertion. In a study at Washington State University in USA, sixty samples of students' writing from a (entry-level) Writing Placement Exam and a (junior-level) Writing Portfolio were examined. The scores of their work unveiled a surprising discovery: a negative relationship exists between students' critical thinking and their writing.
That is to say, the higher students scored in critical thinking, the poorer their writing was, and the other way around with low critical thinking scores and good writing marks. The finding from their study calls into question the existence of relationship between critical thinking and writing.

A study conducted in China by Pei and his colleagues [4] found an insignificant correlation between Chinese EFL university students' critical thinking skill and their argumentative writing. 110 English majors were given a Chinese version of Watson-Glaser Critical Thinking Appraisal test and an EFL argumentative writing test. On the one hand, the results from the tests indicate an insignificant relationship between the two variables. On the other hand, learners with strong critical thinking outperformed the weak ones in several elements of argumentative writing such as relevance, clarity, logicality, profundity, and flexibility.

To date, findings about the relationship between critical thinking and argumentative writing have remained inconsistent. Even poorly investigated in Vietnamese EFL context, to the best of our knowledge, critical thinking is a new concept in Vietnamese educational system. The present paper, henceforth, contributes to the body of critical thinking literature by examining the critical thinking ability of Vietnamese university students and its relationship with their writing argumentative essays.

\section{Research Methodology}

\subsection{Research Questions}

Two questions which guide the enquiry of this research are:

1. What is Vietnamese students' critical thinking ability?

2. What is the relationship between students' critical thinking and their writing argumentative essays?

\subsection{Participants}

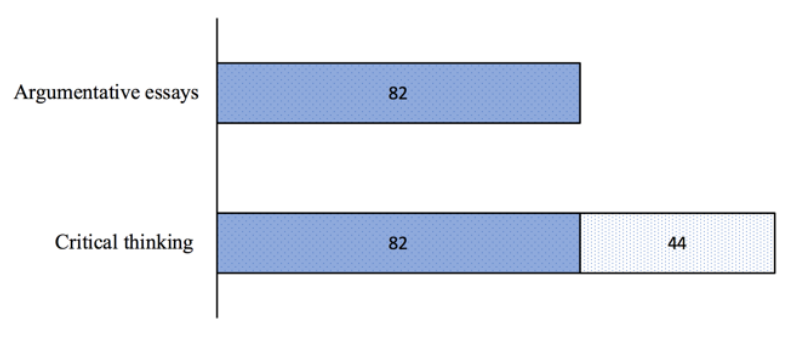

口Students who completed both $\quad$ ¿Students who only answered the questionnaire

Figure 1. Summary of the collected data

126 students at three universities of the Mekong delta, Vietnam took part in the study. They were English majors from the first to the fourth years. Their ages ranged between 19 and 34 with eighty percent being female. Because of Covid-19 pandemic, participants were selected 
via convenience sampling technique in order to collect as much data as possible. All of the participants answered the questionnaire to measure their critical thinking levels while 82 completed the essays, which was used to explore the relationship between their critical thinking ability and their writing performance. Figure 1 illustrates the collected data.

\subsection{Instruments}

Two main instruments used to collect data include critical thinking questionnaire and argumentative essay.

Critical thinking questionnaire (Appendix A). In order to investigate students' critical thinking ability, a three-part questionnaire was utilized. They are (1) participants' background, (2) critical thinking appraisal, and (3) self-report. The first part dealt with demographic questions such as participants' major, year of study, hometown, and gender. It was followed by a list of thirty-four structured items in Part 2 to measure their critical thinking ability which was the main concern of the instrument. The thirty-four items were statements exploring activities that one possibly does when thinking critically about a subject. Participants were asked to rate the frequency of those activities on a 5-point Likert scale starting from never (1 point), to always (5 points). Open-ended questions for participants to self-report were presented in the final part. This questionnaire was developed based on The Delphi Expert Consensus Definition of Critical Thinking that was generally agreed by a panel of forty-six critical thinking experts [16], combined with a critical thinking questionnaire generated by Dr. Peter Honey, a psychologist and founder of Peter Honey Publications Ltd [32].

Argumentative essay test (Appendix B). Students' writing was measured by an argumentative essay test. The essay question includes a prompt introducing two modes of schools' activities about which people had different views: working in a team and working alone. The participants were asked to give their opinion about the matter. This topic was believed to be familiar with university students because their learning in university requires different modes of activities either in a group or by his or herself. According to Hyland's [33], a writing test is invalid if its topic requires special knowledge that test-takers do not possess. Familiar topics, additionally, give participants opportunity to exploit their background knowledge on the given subject [5]. Regarding the duration of the test, it was unlimited to those who submitted it online and forty minutes to others who did it on-the-spot in class. The required length of the writing test was 250 words minimum.

The writing marking rubrics (Appendix C). Besides the questionnaire and the writing test, a rubric for marking argumentative essays was created on the basis of VSTEP (Vietnamese Standardized Test of English Proficiency), and a scoring scheme with "similar interpretations of overall CEFR level classifications” was well recognized by
Vietnamese universities [34]. The four criteria of VSTEP, namely task fulfilment, organization, vocabulary and grammar, were delineated by seven categories in this study. They were topic presentation, thesis statement, supporting data (evidence), refutation (counter argumentation), conclusion, organization (structure and transitions), and language (vocabulary, grammar, and mechanics). Each criterion ranges from 1 (do not match the requirements) to 4 (excellence). Maximum score from seven categories is 28 points. Descriptions for the first five criteria were adapted from Liu's rubric for critical thinking in writing [35]. The other two were derived from VSTEP. The current rubric was well validated by three EFL teachers who are experienced in teaching and marking writing.

\subsection{Procedures}

The three main stages of the data collection procedure were (1) piloting the questionnaire (online), (2) administering the questionnaire to the actual participants (online and on-site), and (3) administering the writing test (online and on-site).

After being validated by experienced EFL teachers and piloted on 30 students of similar background to the official participants, the questionnaire was reliable for the actual study (Cronbach's Alpha $=0.87$ ). The actual research went through two stages: online and on-the-spot. Due to the Covi-19 (coronavirus) pandemic, at first, with the permission of the lecturers in charge, the questionnaire together with the essay test were emailed to students in March and April 2020. However, the response rate was low due to several reasons such as their busy online-study schedule, inaccessible email addresses, and the like. The data was further collected in classrooms (questionnaire and essay completion tasks) as soon as schools were allowed to resume their work.

Before the study, students were informed of the study objectives, questionnaire and writing tests for the clarity of the questions.

To ensure subjectivity and reliability, the data, after collected and coded, were marked by two experienced EFL teachers using the rubric provided by the researcher. A strong positive correlation was obtained $(r=.99, p<0.001)$, which indicates the two sets of scores were almost identical. In other words, the interrater reliability, the level of similarity between different raters, was maintained [36].

The collected data were, then, analyzed using the software SPSS (Statistical Package for the Social Sciences). Findings of the study are reported in the next section.

\section{Findings and Discussion}

\subsection{Findings}

4.1.1. Vietnamese Students' Critical Thinking Ability 
A Descriptive Statistics test was run to identify the critical thinking ability of Vietnamese EFL university students. Results from the questionnaire show that the students were at high level of critical thinking ( $M=3.77$, $S D=.38$ ) as referred to the Oxford's (1990) framework summarized in Table 4. Specifically, $75 \%$ of the participants reported that they were at high and very high levels of critical thinking while the other $25 \%$ appraised themselves as average critical thinkers. Summary of the result from the critical thinking questionnaire is shown in Table 2.

Table 2. Descriptive Statistics of critical thinking (CT)

\begin{tabular}{|c|c|c|c|c|c|}
\hline & $\mathrm{n}$ & Min & Max & Mean & SD \\
\hline CT ability & 126 & 2.62 & 4.76 & 3.77 & .38 \\
\hline Valid N (listwise) & 126 & & & & \\
\hline
\end{tabular}

Table 3. Students' critical thinking per year of study

\begin{tabular}{|c|c|c|c|}
\hline School year & $\mathrm{n}$ & $\mathrm{M}$ & $\mathrm{SD}$ \\
\hline Freshmen & 9 & 3.70 & .41 \\
\hline Sophomores & 44 & 3.71 & .41 \\
\hline Juniors & 38 & 3.78 & .42 \\
\hline Seniors & 35 & 3.84 & .28 \\
\hline Total & 126 & 3.77 & .38 \\
\hline
\end{tabular}

Table 3 compares students' critical thinking ability across four school years. When collating the mean scores of their critical thinking, a gradual rise from freshmen $(M=3.70, S D=.41)$ to seniors $(M=3.84, S D=.28)$ was observed.

A One-Sample $t$-Test was performed to check if there was a significant difference between the mean score from the participants' responses to the questionnaire $(M=3.77$ as high critical thinking level) and the test value of 3.4 (average critical thinking level) in accordance with the adapted framework proposed by Oxford (1990) (Table 4). The result shows a significant difference $(t(125)=10.87$, $p=.00$ ). Hence, it could be concluded that Vietnamese EFL students' critical thinking ability is at high level.

Table 4. Adapted critical thinking levels (Oxford, 1990)

\begin{tabular}{|c|c|c|}
\hline Mean ranges & Frequency & Critical thinking levels \\
\hline $4.5-5.0$ & Almost & Very high \\
\hline $3.5-4.4$ & Often & High \\
\hline $2.5-3.4$ & Sometimes & Average \\
\hline $1.5-2.4$ & Rarely & Low \\
\hline $1.0-1.4$ & Never & Very low \\
\hline
\end{tabular}

Regarding six skills of critical thinking, a Descriptive Statistics test was run to identify students' level with respect to each skill, namely analysis, evaluation, interpretation, inference, explanation, and self-regulation.
Table 5 shows a consistency in learners' ability to analyze, evaluate, interpret, infer, explain, and self-regulate, with the mean scores ranging from 3.60 to 4.01; all were within the high level according to the Oxford's framework (1990). Students scored highest in interpretation $(M=4.01, S D=.53)$ and lowest in explanation $(M=3.60, S D=.53)$. Results from the One-sample $t$-test (Table 6) indicate a statistically significant difference between the high skill scores of the participants in the present study and the test value of 3.4 representing the average level according to the Oxford's framework (1990). Their statistical reports are as follows: analysis $(t(125)=6.57, p=.00)$, evaluation $(t(125)=9.02$, $p=.00)$, interpretation $(t(125)=12.27, p=.00)$, inference $(t(125)=6.04, p=.00)$, explanation $(t(125)=3.93, p=.00)$, and self-regulation $(t(125)=7.16, p=.00)$.

Table 5. Report on core critical thinking skills

\begin{tabular}{|c|c|c|c|c|c|}
\hline & $\mathrm{n}$ & Min & Max & Mean & SD \\
\hline Analysis & 126 & 2.33 & 5.00 & 3.72 & .51 \\
\hline Evaluation & 126 & 2.60 & 5.00 & 3.86 & .53 \\
\hline Interpretation & 126 & 2.67 & 5.00 & 4.01 & .53 \\
\hline Inference & 126 & 2.00 & 5.00 & 3.74 & .59 \\
\hline Explanation & 126 & 2.00 & 5.00 & 3.60 & .53 \\
\hline Self-regulation & 126 & 2.33 & 5.00 & 3.69 & .43 \\
\hline $\begin{array}{c}\text { Valid number of } \\
\text { participants }\end{array}$ & 126 & & & & \\
\hline
\end{tabular}

Table 6. One-Sample $t$-Test on core critical thinking skills

\begin{tabular}{|c|c|c|c|c|c|c|}
\hline & \multicolumn{6}{|c|}{ Test Value $=3.4$} \\
\hline & \multirow[t]{2}{*}{$\mathrm{t}$} & \multirow[t]{2}{*}{$\begin{array}{c}\text { degrees } \\
\text { of } \\
\text { freedom }\end{array}$} & \multirow[t]{2}{*}{$\begin{array}{c}\text { Significance } \\
\text { level } \\
\text { (2-tailed) }\end{array}$} & \multirow[t]{2}{*}{$\begin{array}{c}\text { Mean } \\
\text { Difference }\end{array}$} & \multicolumn{2}{|c|}{\begin{tabular}{|c|}
$95 \%$ \\
Confidence \\
Interval of \\
the \\
Difference \\
\end{tabular}} \\
\hline & & & & & & \\
\hline Analysis & 6.57 & 125 & 0.00 & 0.32 & 0.22 & 0.42 \\
\hline Evaluation & 9.02 & 125 & 0.00 & 0.46 & 0.36 & 0.56 \\
\hline Interpretation & 12.27 & 125 & 0.00 & 0.62 & 0.52 & 0.72 \\
\hline Inference & 6.04 & 125 & 0.00 & 0.34 & 0.23 & 0.45 \\
\hline Explanation & 3.93 & 125 & 0.00 & 0.20 & 0.10 & 0.30 \\
\hline Self-regulation & 7.16 & 125 & 0.00 & 0.29 & 0.21 & 0.37 \\
\hline
\end{tabular}

\subsubsection{Relationship between CT and AW Essays}

A correlation test was executed to investigate the relationship between students' critical thinking ability and their writing argumentative essays. As comparing the marks from their essays and their scores in the critical thinking questionnaire, it revealed that the relationship between the two was statistically insignificant $(r=.16$, $p=.15$ ). Table 7 reports the results from the correlation test. Figure 2 presents the relationship between critical thinking argumentative writing. 
Table 7. Results from the correlation test

\begin{tabular}{|c|c|c|c|}
\hline \multicolumn{2}{|c|}{\begin{tabular}{c} 
Correlations between critical thinking (CT) and argumentative writing \\
\multicolumn{2}{|c|}{}
\end{tabular}} & $\begin{array}{c}\text { Critical } \\
\text { thinking }\end{array}$ & Essay score \\
\hline \multirow{4}{*}{ Critical thinking } & Pearson Correlation & 1 & .16 \\
\cline { 2 - 4 } & Sig. (2-tailed) & & .15 \\
\cline { 2 - 4 } & $\mathrm{N}$ & 82 & 82 \\
\hline \multirow{3}{*}{ Essay score } & Sig. (2-tailed) & .15 & 1 \\
\cline { 2 - 4 } & Pearson Correlation & .16 & 82 \\
\cline { 2 - 4 } & $\mathrm{N}$ & 82 & \\
\cline { 2 - 4 } & & & \\
\hline
\end{tabular}

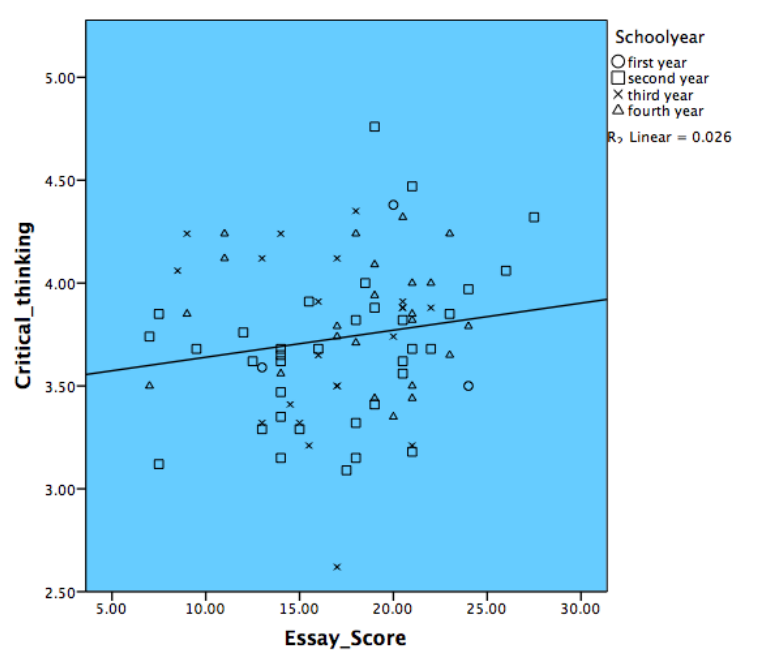

Figure 2. Correlation between $\mathrm{CT}$ and AW

Correlation tests were repeated on seven criteria of the argumentative essay's marking rubrics including (1) topic presentation, (2) thesis statement, (3) supporting data (evidence), (4) refutation (counter argumentation), (5) conclusion, (6) organization (structure and transitions), and (7) language (vocabulary, grammar, and mechanics) in order to determine whether any of these sub categories was associated with test-takers' critical thinking ability. The results reveal that none of these criteria was correlated with students' critical thinking ability (Table 8). The highest correlation found was organization at $0.22(p=.05)$ while the lowest was topic presentation at $0.08(p=.49)$.

Table 8. Correlation between CT and AW category

\begin{tabular}{|c|c|c|}
\hline & \multicolumn{2}{|c|}{ Critical thinking } \\
\hline & Correlation (r) & $\begin{array}{c}\text { Statistical } \\
\text { significance (p) }\end{array}$ \\
\hline Topic presentation & 0.08 & 0.49 \\
\hline Thesis statement & 0.12 & 0.27 \\
\hline Supporting data & 0.14 & 0.21 \\
\hline Refutation & 0.17 & 0.12 \\
\hline Conclusion & 0.1 & 0.38 \\
\hline Organization & 0.22 & 0.05 \\
\hline Language & 0.16 & 0.16 \\
\hline
\end{tabular}

\subsection{Discussion}

This section discusses the key findings of the research regarding two research questions.

\section{A) Research Question One: What is Vietnamese EFL university students' critical thinking ability?}

Concerning critical thinking ability of Vietnamese EFL university students, three interesting findings were discovered in the present study.

First, the most striking result to emerge from the data is that Vietnamese EFL university students are at high level of critical thinking. The current finding is in contradiction with previous research in the field [e.g., 18, 19, 20]. For example, the study of Nguyen [20] indicates that non-English major students at a province in the Mekong delta are weak and average at critical thinking as resulted from their answers to a critical thinking disposition questionnaire. Similarly, Lam [18] found that high school students at a rural area demonstrated weak and average level of critical thinking when they expressed their opinion about a well-known Vietnamese legend. In a similar manner, Nguyen [19] highlights a lack of critical thinking among English-majored students in an urban city as perceived by their in-charged teachers.

Additionally, this finding challenges the previous studies where Asian students' critical thinking is concerned. Various authors claim that the social practices of group harmony and conformity in such culture impede the development of critical thinking ability [37]. For instance, a study from Pei and his colleagues [4] stresses that English-majored Chinese students show a syndrome of critical thinking absence in classroom practices such as overt questioning or debating ideas in class. Similar classroom behaviours are noticed from Japanese EFL students in Okada's [21] study. She argues that such difficulties are caused because these activities (e.g., asking questions, expressing opinion in class) are not suitable with their cultural values of harmony and confrontation avoidance.

There are several possible explanations for these differences. Firstly, the different methods of obtaining data may be the reason for the different results. By way of example, Lam [18], and Nguyen [19] employ a writing test with a marking rubric for assessing critical thinking, and interviews for personal evaluation from observers (in-charge teachers), respectfully. In this study, students self-report the frequency of cognitive activities they do when thinking about a subject. Data from the research indicate that students often practice critical thinking activities such as searching out for further clarification when the given information is deficient, or checking the source of information to evaluate its reliability. Based on the frequency of these activities, their critical thinking ability was estimated. Secondly, the teaching and learning environment may influence the development of critical thinking among students. In fact, Vo and Moore [38] 
indicate that appropriate teaching methods can overcome the presumed cultural barrier. As a matter of fact, although Vietnamese and Chinese students share similar cultural values such as harmony and hierarchy, teaching and learning practices are reported to be different. In their study, Pei and his colleagues [4] admitted the drawbacks of teaching methods in Chinese education. Emphasis on imitation, rote memorisation, and repeated drilling in their pedagogical practices are acknowledged to hinder the growth of critical thinking [4]. In contrast, to the researcher's knowledge, the English programmes in the current study's settings are often task-based and project-driven. Students are regularly required to participate in classroom's discussion, or work in groups to conduct presentations. These activities are likely to provide opportunities for students to practice making appropriate choices to meet the requirements of the task or the project, solving problems occurred during group works, being creative in their performance and the like. As a result, their critical thinking seems to develop gradually. In addition to the first two reasons, the Internet era of today may promote critical thinking outside of the classroom. Most students have accessed to the Internet and social media in particular. Because of the vast sea of information in their hands (namely, their smartphone or computers) since the young age, students may have unconsciously learnt to select the right source of information and express their opinion.

Second, students' critical thinking ability is likely to be associated with their years of study in university. In other words, when comparing their critical thinking ability, the data illustrated an increase from freshmen, sophomores, juniors, to seniors, respectfully. This finding is consistent with previous results [e.g., 39, 40]. For instance, Ventura and his colleagues [39] highlight the effects of collective college experience on students' cognitive enhancement as reported in a large body of literature. Particularly, it is concluded in Huber's and Kuncel's [40] study that students' critical thinking tends to improve after four years of college. In the current research, an assumption could be drawn that learning activities in English-majored classes may enhance students' critical thinking. With four primary language skills such as reading, listening, speaking, and writing, students are encouraged to participate in various activities such as finding main ideas, looking for details to support the ideas, inferring and interpreting the meaning behind authors' or speakers' words, expressing their thoughts, seeking for errors and fixing them. Besides those, when working on tasks, projects, or presentations to which Vietnamese EFL learners in the current study's context are regularly required, they have to analyse the tasks and evaluate the situation before making appropriate decisions to compete their requirements. Such activities are closely related to elements of critical thinking which are analysis, evaluation, interpretation, inference, explanation, and self-regulation. That could explain the reasons for English-majored students who had more experience in learning also scored higher in the critical thinking questionnaire.

Third, comparing to being good at interpretation, Vietnamese EFL university students' ability to expressing themselves is not great. This finding is in line with Okada [21]'s study. The Japanese students in her research are also reported to face difficulty in expressing opinions due to its contradiction with Japanese value which is living in harmony with others. In that respect, Vietnamese culture shares similar value. As noted in Pham [41]'s book on Vietnamese cultural values, harmony is reflected through indirect communication style, and avoidance of conflict and confrontation [41]. That possibly unfolds factors affecting Vietnamese students' trouble in expressing opinions.

\section{B) Research Question Two: What is the relationship between students' $C T$ and their AW essays?}

Contrary to expectations, no relationship was observed between Vietnamese EFL students' critical thinking and their writing argumentative essays. This finding is inconsistent with most of previous empirical studies in the area [e.g., 7, 26-28, 42, 43]. For example, several studies found that integrating critical thinking into teaching argumentative writing can help EFL learners enhance their writing performance [e.g., 28, 30], or improve their English language competence [29].

Although the finding of the present study significantly differs from most previous results reported in the literature, it provides additional support for the few other studies. They indicate that the relationship between critical thinking and argumentative writing is not always significant and sometimes even negative [4, 31]. Whereas Pei and his colleagues [4] found an insignificant correlation between Chinese EFL students' critical thinking and argumentative writing, Condon and Kelly-Riley [31] even found it to be negative among students at Washington State University. In fact, their study unveils that the most problematic writing was produced by students with the highest critical thinking score, and vice versa.

Despite the seemingly surprising mismatch between critical thinking and writing, two possible rationalisations could be generated: affective dispositions, and English language proficiency. The first reason refers to students' "consistent internal motivation" to make use of their critical thinking skills [44]. According to Facione and his associates [44], critical thinking skills and dispositions are two separate dimensions. A person may have the skill and ability but their internal motivation to use it may lack consistency. By the same token, Condon and Kelly-Riley [31] argue that asking students to write does not guarantee them to apply their critical thinking into it. It could be a result of lacking interest in the topic or even their emotional and physical condition at that moment.

Another explanation for this mismatch between students' critical thinking and their writing argumentative essays 
could be their English language proficiency. Pei and his colleagues [4] indicated that English proficiency plays a crucial role in demonstrating students' writing ability. Low linguistic proficiency may hinder EFL students from critical thinking. Even when students are high critical thinkers, linguistic barrier may prevent them from expressing their thoughts. In fact, if students do not have sufficient knowledge of the field, they are unlikely to argue convincingly about an issue [45].

\section{Conclusions}

This research explored the critical thinking ability of Vietnamese EFL students and the relationship between students' critical thinking and their writing argumentative essays. The findings of the research reveal that students had high critical thinking level. Of the six core critical thinking skills (namely analysis, evaluation, interpretation, inference, explanation, and self-regulation), students are strongest at interpretation and weakest at explanation skill. Additionally, there is a steady increase in their critical thinking level across the four grades from freshmen to seniors. However, no correlation was observed between their critical thinking ability and writing argumentative essays.

This study extends understanding of literature on critical thinking and its practices in Vietnamese tertiary education. Since it is still a new concept in the country's educational system, the findings from this study imply a positive outcome of recent pedagogical practices in EFL classes in the Mekong delta region. Instructional methods and activities employed by these EFL teachers may well promote cognitive development among their students.

The mismatch between critical thinking ability and students' writing, anyhow, suggests urgent actions from EFL teachers. Feasible solutions are needed to foster students' implementation of their cognitive skills into their writing and other language skills. This requires cooperation among textbook creators, curriculum developers, and importantly the support from the government's educational policymakers.

One limitation of the present study is the sample size due to the impact of Covi-19 (coronavirus) pandemic. Future research is needed on a larger scale with a more balanced gender distribution.

\section{About the Authors}

Nguyen Son Tuyen teaches English to teenagers at a foreign language center in Vinh Long city, Vietnam. She is an MA candidate in Principles and Methods in English Language Education at School of Foreign Languages, Can Tho University, Vietnam. Her research interests involve writing skills and strategies, and cognitive skill development. She is also interested in promoting IT learning experience for EFL learners.

Nguyen Buu Huan is a Senior Lecturer in English at School of Foreign Languages, Can Tho University. His doctoral research focuses on teacher beliefs and changes in science education at tertiary levels. His research interests include teacher beliefs, teacher change, ESP, and curriculum planning. He is now engaged in writing teaching materials for both EFL and ESP students at the university. 


\section{APPENDIX A}

\section{Critical Thinking Questionnaire}

Adapted from Honey [32] and the Delphi report [16]

Please put a tick $(\checkmark)$ in the box that is true in your situation. There is no right or wrong answer. $1=$ never $\quad 2=$ rarely $\quad 3=$ sometimes $4=$ often $5=$ always

\begin{tabular}{|c|c|c|c|c|c|c|}
\hline Items & Statements & 1 & 2 & 3 & 4 & 5 \\
\hline 1 & $\begin{array}{l}\text { I ask for information from other people to expand my understanding about a topic. } \\
\text { (Tôi tiếp thu thông tin tù̀ nhüng người khác để mở rộng hiểu biết của tôi về một chủ đề.) }\end{array}$ & & & & & \\
\hline 2 & $\begin{array}{l}\text { I ask questions to help me understand more about a topic. } \\
\text { (Tôi đặt câu hỏi để giúp bản thân hiểu rõ hon về một chủ đề.) }\end{array}$ & & & & & \\
\hline 3 & $\begin{array}{l}\text { I break down the information so that I can see how the idea is organized and developed. } \\
\text { (Tôi chia nhỏ thông tin để thấy cách các ý tướng được sắp xếp và phát triển nhu thế nào.) }\end{array}$ & & & & & \\
\hline 4 & $\begin{array}{l}\text { I carefully look at an idea to see if it is logical. } \\
\text { (Tôi cẩn thận xem xét một ý tưởng để thấy nó có hợp lý hay không.) }\end{array}$ & & & & & \\
\hline 5 & $\begin{array}{l}\text { I check the proof of an argument to decide if it is strong enough to believe in. } \\
\text { (Tôi xem xét bằng chứng của một tranh luận để quyết định nó có đáng tin tuởng hay không.) }\end{array}$ & & & & & \\
\hline 6 & $\begin{array}{l}\text { I check the source of information to see if it’s trustworthy. (e.g.: well-known newspaper, official TV } \\
\text { channels instead of a youtube channel...) } \\
\text { (Tôi kiểm tra nguồn gốc của thông tin có đáng tin cậy không (ví dü: báo chí chính thống, kênh truyền hình } \\
\text { chinh thống thay vì kênh youtube...)) }\end{array}$ & & & & & \\
\hline 7 & $\begin{array}{c}\text { I check whether someone's opinion can be trusted. } \\
\text { (Tôi kiểm tra xem ý kiến cá nhân của ai đó có đáng tin hay không.) }\end{array}$ & & & & & \\
\hline 8 & $\begin{array}{c}\text { I consider new information to see if I need to come up with a new conclusion about a previous problem. } \\
\text { (Tôi xem xét các thông tin mói đểxem liệu tôi có phải đua ra một kết luận mói cho một vấn đề truớc đó hay } \\
\text { không.) }\end{array}$ & & & & & \\
\hline 9 & $\begin{array}{l}\text { I distinguish main points from secondary points. } \\
\text { (Tôi phân biệt các điểm chinh với các điểm phụ.) }\end{array}$ & & & & & \\
\hline 10 & $\begin{array}{l}\text { I double-check facts and opinions to make sure they are correct. } \\
\text { (Tôi kiểm tra lại các sự thật và ý kiến để bảo đảm rằng chúng đúng.) }\end{array}$ & & & & & \\
\hline 11 & $\begin{array}{l}\text { I explain reasons for my decision or my choice. } \\
\text { (Tôi giải thích lý do cho quyết đinh hay lựa chọn của tôi.) }\end{array}$ & & & & & \\
\hline 12 & $\begin{array}{l}\text { I express my thoughts clearly. } \\
\text { (Tôi bày tỏ suy nghĩ của mình một cách rõ ràng.) }\end{array}$ & & & & & \\
\hline 13 & $\begin{array}{l}\text { I find solutions to correct mistakes in my work. } \\
\text { (Tôi tìm cách sửa các lỗi trong bài của mình.) }\end{array}$ & & & & & \\
\hline 14 & $\begin{array}{l}\text { I find the main ideas of people's arguments. } \\
\text { (Tôi tìm điểm trọng tâm trong các tranh luận của người khác.) }\end{array}$ & & & & & \\
\hline 15 & $\begin{array}{c}\text { I don’t have evidence and reasons to respond to arguments against my conclusion. } \\
\text { (Tôi không có bằng chứng và lý lẽ để hồi đáp các phản biện.) }\end{array}$ & & & & & \\
\hline 16 & $\begin{array}{l}\text { I ignore emotional language to avoid being influenced by personal opinions. } \\
\text { (Tôi bỏ qua ngôn tù cảm xúc trong câu nói của người khác để tránh cám nhận cá nhân của họ làm ảnh } \\
\text { hưởng suy nghĩ của tôi.) }\end{array}$ & & & & & \\
\hline 17 & $\begin{array}{c}\text { I look back at my work to find any mistake or error. } \\
\text { (Tôi xem lại bài để tìm các lỗi nếu có.) }\end{array}$ & & & & & \\
\hline 18 & $\begin{array}{l}\text { I look for similarities between different problems. } \\
\text { (Tôi tìm kiếm điểm giống nhau giữa các vấn đề khác nhau.) }\end{array}$ & & & & & \\
\hline 19 & $\begin{array}{l}\text { I make a decision by myself, not because of people's opinion. } \\
\text { (Tôi tư đưa ra quyết định thay vì bị ảnh hướng bởi ý kiến của người khác.) }\end{array}$ & & & & & \\
\hline 20 & $\begin{array}{l}\text { I make notes on the main points of an argument. } \\
\text { (Tôi luu ý các điểm chính của một lập luận.) }\end{array}$ & & & & & \\
\hline 21 & $\begin{array}{l}\text { I let my feelings affect my evaluation of a subject. } \\
\text { (Tôi để cảm xúc hay định kiến của minh làm ảnh hwởng đánh giá của tôi về một vấn đề.) }\end{array}$ & & & & & \\
\hline 22 & $\begin{array}{l}\text { I raise questions when the information is not given enough. } \\
\text { (Tôi đặt câu hỏi khi thông tin đura ra chua đầy đủ.) }\end{array}$ & & & & & \\
\hline 23 & $\begin{array}{l}\text { I realise the hidden message from someone's facial expression or body language. } \\
\text { (Tôi nhận ra thông điệp ẩn chúa qua biểu cảm gưong mặt, hay ngôn ngũ cơ thể của người khác.) }\end{array}$ & & & & & \\
\hline 24 & $\begin{array}{l}\text { I recognize the difference between facts and opinions. } \\
\text { (Tôi phân biệt giữa sự thật và ý kiến cá nhân.) }\end{array}$ & & & & & \\
\hline 25 & $\begin{array}{l}\text { I rephrase information I have read or seen into my own words to help me understand it. } \\
\text { (Tôi chuyển thông tin minh đã đọc hoặc xem thành ngôn ngũ của chính minh để giúp tôi hiểu nó tốt hơn.) }\end{array}$ & & & & & \\
\hline
\end{tabular}


APPENDIX A Continuous

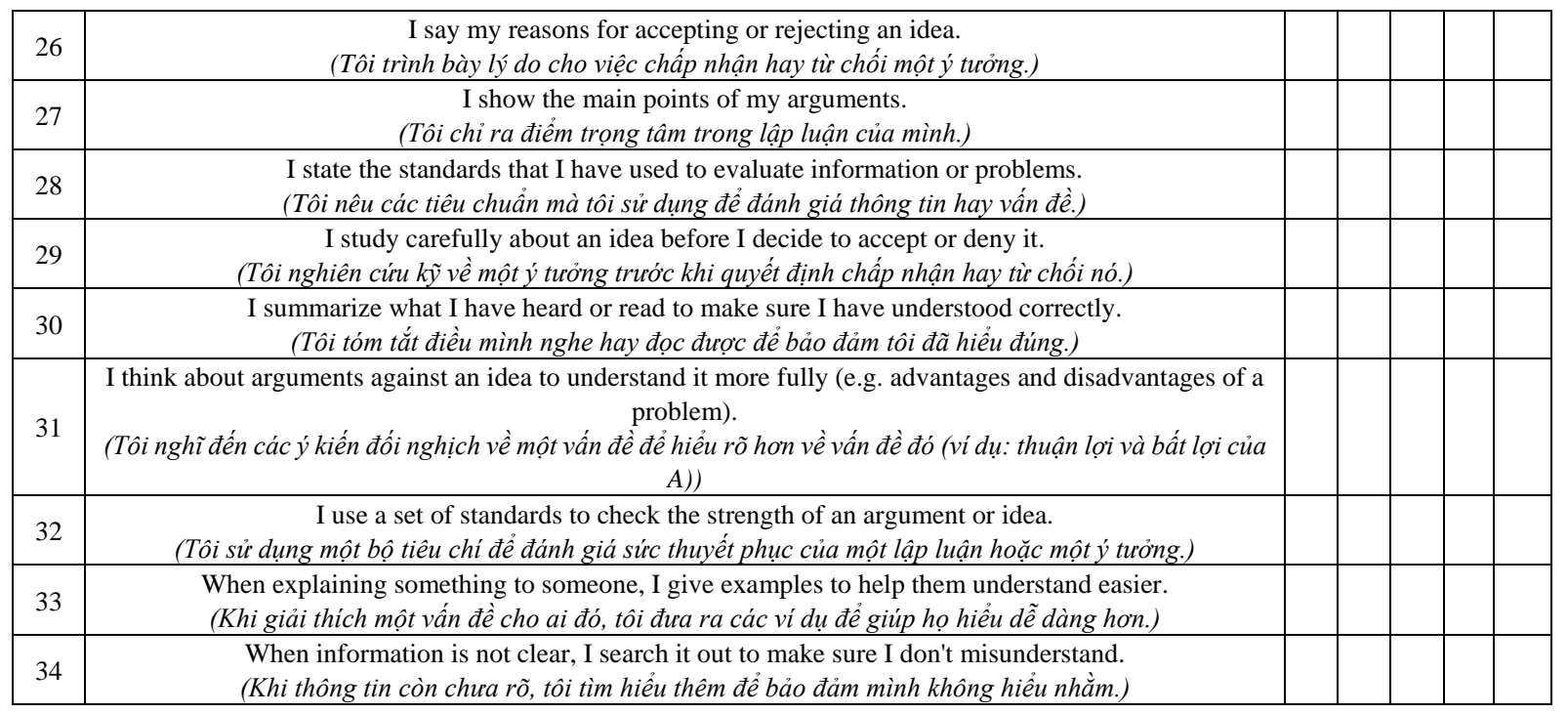

\section{APPENDIX B}

\section{Writing Test}

You should spend about 40 minutes on this task.

At schools, students are often asked to work in a team or work individually. While some people argue that it is more effective to work alone, others think working as a team brings more benefits.

What are your views of this argument?

Give reasons for your answer and include any relevant examples from your own knowledge or experience.

You should write at least 250 words. 


\section{APPENDIX C}

\section{Rubric for Marking Argumentative Essays}

Adapted from VSTEP and Liu's (2014)

\begin{tabular}{|c|c|c|c|c|}
\hline & 1 & 2 & 3 & 4 \\
\hline $\begin{array}{c}\text { TOPIC } \\
\text { PRESENTATION } \\
\text { (background } \\
\text { information) }\end{array}$ & $\begin{array}{l}\text { Does not identify or } \\
\text { explain main issue; } \\
\text { Is confused. }\end{array}$ & $\begin{array}{l}\text { Identifies main issue, } \\
\text { does not explain clearly. }\end{array}$ & $\begin{array}{l}\text { Identify main issue/topic } \\
\text { clearly, explains in } \\
\text { limited fashion. }\end{array}$ & $\begin{array}{l}\text { Identify main issue/topic } \\
\text { clearly, explains fully by } \\
\text { discussing subsidiary } \\
\text { and/or other relevant } \\
\text { issues. }\end{array}$ \\
\hline $\begin{array}{c}\text { THESIS } \\
\text { STATEMENT }\end{array}$ & $\begin{array}{l}\text { Fails to identify and state } \\
\text { his/her own perspective } \\
\text { on the issue/ topic. }\end{array}$ & $\begin{array}{l}\text { Identifies and states } \\
\text { own perspective, but } \\
\text { fails to clarify own } \\
\text { perspective versus other } \\
\text { opposing views. }\end{array}$ & $\begin{array}{l}\text { Identifies and states own } \\
\text { perspective, but does so } \\
\text { in a limited fashion. }\end{array}$ & $\begin{array}{l}\text { Identifies and states own } \\
\text { perspective, and considers } \\
\text { it in light of other } \\
\text { opposing view. }\end{array}$ \\
\hline $\begin{array}{l}\text { SUPPORTING DATA } \\
\text { (evidence) }\end{array}$ & $\begin{array}{l}\text { Fails to support own } \\
\text { perspective with } \\
\text { appropriate data. }\end{array}$ & $\begin{array}{c}\text { Supports own } \\
\text { perspective with } \\
\text { limited, insufficient } \\
\text { data. }\end{array}$ & $\begin{array}{c}\text { Supports own } \\
\text { perspective with data, } \\
\text { but data are weak. }\end{array}$ & $\begin{array}{l}\text { Supports own perspective } \\
\text { with sufficient, } \\
\text { convincing data. }\end{array}$ \\
\hline $\begin{array}{l}\text { REFUTATION } \\
\qquad \text { (counter } \\
\text { argumentation) }\end{array}$ & $\begin{array}{l}\text { Does not consider } \\
\text { opposing views regarding } \\
\text { the topic/ issue. }\end{array}$ & $\begin{array}{c}\text { Considers opposing } \\
\text { views that are } \\
\text { irrelevant/ inappropriate } \\
\text { to the topic/issue. }\end{array}$ & $\begin{array}{l}\text { Considers opposing } \\
\text { views, but does so in a } \\
\text { limited fashion. }\end{array}$ & $\begin{array}{l}\text { Considers opposing } \\
\text { views, and refutes them } \\
\text { logically and clearly. }\end{array}$ \\
\hline CONCLUSION & $\begin{array}{l}\text { Does not summarize } \\
\text { main points. } \\
\text { Does not provide } \\
\text { commentary. }\end{array}$ & $\begin{array}{l}\text { Summarizes main } \\
\text { points. } \\
\text { Does not provide } \\
\text { commentary. }\end{array}$ & $\begin{array}{l}\begin{array}{c}\text { Summarizes topics } \\
\text { effectively. }\end{array} \\
\text { Provides Commentary. }\end{array}$ & $\begin{array}{c}\text { Effectively summarizes } \\
\text { and goes beyond restating } \\
\text { the thesis. } \\
\text { Provides logical and } \\
\text { well-thought-out } \\
\text { commentary }\end{array}$ \\
\hline $\begin{array}{l}\text { ORGANIZATION } \\
\text { (structure \& } \\
\text { transitions) }\end{array}$ & $\begin{array}{l}\text { Has no organizational } \\
\text { features. }\end{array}$ & $\begin{array}{l}\text { Presents information } \\
\text { and ideas with some } \\
\text { organization. } \\
\text { Uses basic high } \\
\text { frequency linking words } \\
\text { and cohesive devises }\end{array}$ & $\begin{array}{l}\text { Organizes information } \\
\text { and ideas coherently. } \\
\text { Uses a range of linking } \\
\text { words and cohesive } \\
\text { devices, but does so in a } \\
\text { limited fashion. }\end{array}$ & $\begin{array}{l}\text { Organizes information } \\
\text { and ideas logically. } \\
\text { Uses a range of cohesive } \\
\text { devices and } \\
\text { organizational patterns } \\
\text { flexibly and } \\
\text { appropriately. }\end{array}$ \\
\hline $\begin{array}{c}\text { LANGUAGE } \\
\text { (vocabulary, grammar, } \\
\text { \& mechanics) }\end{array}$ & $\begin{array}{l}\text { Uses only a few isolated } \\
\text { words. Cannot use } \\
\text { sentence form at all. } \\
\text { Makes distracting errors } \\
\text { in punctuation, spelling, } \\
\text { capitalization. }\end{array}$ & $\begin{array}{l}\text { Uses basic vocabulary } \\
\text { and simple structures } \\
\text { with some errors that } \\
\text { distort the meaning. } \\
\text { Uses punctuation, } \\
\text { spelling, capitalization } \\
\text { correctly with some } \\
\text { errors. (3-4) }\end{array}$ & $\begin{array}{l}\text { Uses a sufficient range of } \\
\text { vocabulary, both simple } \\
\text { and complex structures. } \\
\text { Uses punctuation, } \\
\text { spelling, capitalization } \\
\text { correctly with few errors. } \\
(1-2)\end{array}$ & $\begin{array}{l}\text { Uses a wide range of } \\
\text { vocabulary and varied } \\
\text { structures precisely and } \\
\text { flexibly. } \\
\text { Uses punctuation, } \\
\text { spelling, capitalization } \\
\text { correctly with no errors. }\end{array}$ \\
\hline
\end{tabular}

\section{REFERENCES}

[1] R. W. Paul, "The state of critical thinking today," New Directions for Community Colleges, vol. 130, pp. 27-40, 2005.

[2] J. Dewey, "How we think: A restatement of the relation of reflective thinking to the educative process." Massachusetts: D.C. Heath and Company, 1933, p.^pp. Pages.

[3] J. Moon, Critical thinking: An exploration of theory and practice. New York: Routledge, 2008.
[4] Z. Pei, C. Zheng, M. Zhang, and F. Liu, "Critical thinking and argumentative writing: Inspecting the association among EFL leaners in China," English Language Teaching, vol. 10, no. 10, pp. 31-42, 2017.

[5] R. N. Indah, "Critical thinking, writing performance and topic familiarity of Indonesian EFL learners," Journal of Language Teaching and Research, vol. 8, no. 2, pp. 229-236, 2017.

[6] (2018). Chưong trình giáo duc phổ thông tổng thể (The new general educational programs in Vietnam). Available: https://moet.gov.vn/content/tintuc/Lists/News/Attachments/ 4944/CTGDTT_2872017.pdf

[7] F. Golpour, "Critical thinking and EFL learners' performance on Different Writing Modes," Journal of 
Pan-Pacific Association of Applied Linguistics, vol. 18, no. 1, pp. 103-119, 2014.

[8] T. T. Pham, "Tư duy phản biện trong học kỹ năng nói tiếng Anh (Critical thinking in speaking English)," Tạp chí giáo duc (Journal of Education of MOET), pp. 164-165, 2015.

[9] D. Nunan, Second language teaching and learning. Boston: Heinle \& Heinle, 1999.

[10] M. Lane, Plato's progeny: How Socrates and Plato still captivate the modern mind (Classical Inter/Faces). London: Bloomsburry Academic, 2001.

[11] J. Dewey, "How we think." Massachusetts: D.C. Heath and Company, 1910, p.^pp. Pages.

[12] R. H. Ennis, "Critical thinking assessment," Theory into Practice, vol. 32, no. 3, pp. 179-186, 1993.

[13] B. S. Bloom, M. D. Engelhart, E. J. Furst, W. H. Hill, and D. R. Krathwohl, Taxonomy of educational objectives: The classification of educational goals. Handbook 1: Cognitive domain (Taxonomy of educational objectives). Michigan: Longman, 1956.

[14] R. H. Ennis, "A logical basis for measuring critical thinking skills," Educational Leadership, vol. 40, no. 10, pp. 44-48, 1985.

[15] R. H. Ennis, "Critical thinking dispositions: Their nature and assessability," Informal Logic, vol. 18, no. 2 \& 3, pp. 165-182, 1996.

[16] P. A. Facione, "Critical thinking: A statement of expert consensus for purposes of educational assessment and instruction (The Delphi report)," 1990.

[17] D. F. Halpern, "Thought and knowledge: An introduction to critical thinking." New York: Psychology Press, 2014, p.^pp. Pages.

[18] T. T. T. Lam, "Tác động của câu hỏi đối với năng lực tư duy phản biện của học sinh trung học phổ thông trong dạy học đọc hiểu văn bản (The impact of questions on high school students' critical thinking ability in teaching to read texts)," Master of Education, School of Education, Can Tho University, 2016.

[19] B. T. T. Nguyen, "Critical thinking in a Vietnamese tertiary English as a foreign language context: Current practices and prospects," Doctor of Education, University of Technology Sydney, Sydney, 2016.

[20] D. T. K. Nguyen, "The effects of problem-based learning on non-English major seniors' critical thinking enhancement," Master in Education, Can Tho University, Can Tho, 2010.

[21] R. Okada, "Conflict between critical thinking and cultural values: Difficulty asking questions and expressing opinions in Japan," Asian Education Studies, vol. 2, no. 1, pp. 91-98, 2017.

[22] C. Nguyen, "Barriers to communication between Vietnamese and non-Vietnamese," Journal of Vietnamese Studies, vol. 1, no. 4, pp. 40-45, 1991.

[23] H. D. Brown, Language assessment: Principles and classroom practice. New York: Pearson Education, 2004.

[24] K. Hyland, "A genre description of the argumentative essay," RELC Journal, vol. 21, no. 1, pp. 66-78, 1990.
[25] K. Glasswell, J. Parr, and M. Aikman, "Development of the asTTle Writing assessment rubrics for scoring extended writing tasks," University of Auckland, Technical Report 6, Project as TTle 15/08/2020 2001, Available: https://www.researchgate.net/publication/254962718_Deve lopment_of_the_asTTle_Writing_Assessment_Rubrics_for _Scoring_Extended_Writing_Tasks.

[26] M. R. Hashemi, S. Behrooznia, and F. M. Mahjoobi, "A critical look into Iranian EFL university students' critical thinking and argumentative writing," Iranian Journal of Applied Linguistics, vol. 17, no. 1, pp. 71-92, 2014.

[27] D. D. Preiss, J. C. Castillo, P. Flotts, and E. S. Martin, "Assessment of argumentative writing and critical thinking in higher education: Educational correlates and gender differences," Learning and Individual Differences, vol. 28, pp. 193-203, 2013.

[28] N. Nejmaoui, "Improving EFL learners' critical thinking skills in argumentative writing," English Language Teaching, vol. 12, no. 1, pp. 98-109, 2018.

[29] S. Widyastuti, "Fostering critical thinking skills through argumentative writing," Cakrawala Pendidikan: Jurnal Ilmiah Pendidikan, vol. 17, no. 2, pp. 182-189, 2018.

[30] M. Fahim and M. Mirzaii, "Improving EFL argumentative writing: A dialogic critical thinking approach," International Journal of Research Studies in Language Learning, vol. 3, no. 1, pp. 3-20, 2014.

[31] W. Condon and D. Kelly-Riley, "Assessing and teaching what we value: The relationship between college-level writing and critical thinking abilities," Assessing Writing, vol. 9, pp. 56-75, 2004.

[32] P. Honey. (2004). Critical thinking questionnaire. Available: www.peterhoney.com

[33] K. Hyland, Second language writing (Cambridge language education). New York: Cambridge University Press, 2003.

[34] J. Dunlea et al., "APTIS-VSTEP comparability study: Investigating the usage of two EFL tests in the context of higher education in Vietnam," in "British Council Validation Series," 2018, Available: https://www.britishcouncil.org/sit es/default/files/aptis-vstep_study.pdf.

[35] F. Liu, "Investigating critical thinking in the argumentative writing of English majors at a mainland Chinese university: Implications for policy changes," $\mathrm{PhD}$, The Hong Kong Institute of Education, 2014.

[36] F. E. Saal, R. G. Downey, and M. A. Lahey, "Rating the ratings: Assessing the psychometric quality of rating data," Psychological Bulletin, vol. 88, no. 2, pp. 413-428, 1980.

[37] P. Stapleton, "Assessing critical thinking in the writing of Japanese university students: Insights about assumptions and content familiarity," Written communication, vol. 18, pp. 506-548, 2001.

[38] A. T. N. Vo and S. H. Moore, "Viewing critical thinking in English language teaching through a cultural lens: What the perceptions of Vietnamese university teachers and students tell us," English Australia Journal, vol. 35, no. 2, pp. 18-24, 2019.

[39] M. Ventura, E. Lai, and K. DiCerbo, Skills for today: What 
we know about teaching and assessing critical thinking (Skills for today). London: Pearson, 2017.

[40] C. R. Huber and N. R. Kuncel, "Does college teach critical thinking? A meta-analysis," Review of Educational Research, vol. 86, no. 2, pp. 431-468, 2016.

[41] N. T. H. Pham, Communicating with Vietnamese in Intercultural Contexts: Insights into Vietnamese Values. Can Tho: Vietnam Education Publishing House, 2011.

[42] H. S. Afshar, H. Movassagh, and H. R. Arbabi, "The interrelationship among critical thinking, writing an argumentative essay in an L2 and their subskills," The Language Learning Journal, vol. 45, no. 4, pp. 419-433,
2017.

[43] T. T. M. Nguyen and Q. T. T. Bui, "The effects of grouping types on promoting critical thinking in EFL collaborative writing," Journal of Science Ho Chi Minh City Open University, vol. 9, no. 5, pp. 102-112, 2019.

[44] P. A. Facione, N. C. Facione, and C. A. Giancarlo, "The disposition toward critical thinking: Its character, measurement, and relationship to critical thinking skill," Informal Logic, vol. 20, no. 1, pp. 61-84, 2000.

[45] S. R. Mehta and R. I. Al-Mahrooqi, "Can thinking be taught? Linking critical thinking and writing in an EFL context," RELC Journal, vol. 46, no. 1, pp. 23-36, 2014. 